\title{
THE INFLUENCE OF BIOSTIMULATORS IN THE GROWTH OF SOME SHRUBS
}

\author{
Gheorghe-Emil Bandici ${ }^{1}$, Ileana Ardelean ${ }^{1}$, Cornelia Purcărea ${ }^{1}$ \\ ${ }^{1}$ University of Oradea, Faculty of Environment Protection, Department of Agricultural, Oradea, Romania \\ Corresponding author: University of Oradea, Faculty of Environment Protection, Department of Agricultural, 26 Magheru Str., zip code: \\ 410048, Oradea, Romania, tel.: 004059412550, fax. 0040259416274, \\ e-mail: gbandici@yahoo.com
}

Key words: IAA, NAA, procaine, biostimulators, seedlings, rooting, growth substances

Summary

More sensitive than Mimosa pudica and more beautiful than any adornment detached from nature by man, the azalea (Azaleea indica) gathers through its shapes a real symphony of colours and enchanting hues, of elegant shapes, having no rival in the flower world.

The azalea can multiply through seeds and vegetatively: seedlings, grafting, layering.

The widest reproduction method remains that through semilignified seedlings, a method that can be used throughout the year avoiding the months less favourable for propagation by seedlings, with poor light: November and October. The best results are given by the spring propagations by seedlings (February-March) and the summer propagations by seedlings (July-August). The rooting can last for 12-14 weeks until the seedlings can be transplanted in flower pots without risks.

A wide application in horticultural practice is the use of growth substances, that take part in the faster formation of roots and in a higher percent for species of plants, that, normally, root with difficulty through seedlings. Under this aspect, many synthetical compounds have proved to be very active (IAA, NAA, IBA, 2,4,5-T acid etc.) (3,4).

\section{INTRODUCTION}

The ornamental ligneous species can multiply vegetatively through propagation by seedlings, grafting, layering, separation of the bush, propagation by basal shoots. The most often used reproduction method in the case of most species is by seedlings, the material used for this type of reproduction being the seedlings, meaning those portions of the plant that, placed in favourable vegetation conditions according to the principle of restitution, restore organisms that are identical with those of which they were harvested $(1,10)$.

The rooting medium that gave best results was sand from which the coarse and the fine factions were removed. Transplants about 4-12 months old were used as ortets, some of them repeatedly (8). Single node cuttings with part of one leaf were tested. In early experiments "first top node" cuttings were much poorer than cuttings which included second or third nodes from the apex, it was too early to conclude how cuttings from lower down on the ortet would perform (12). There was some indication that better rooting occurred in cuttings from younger than older ortets $(2,6)$.

No clear trend resulted from tests of shading cuttings, though it seemed to promote rooting in younger "first top node" cuttings. Hormone treatment with IAA and IBA suspended in talc seemed to have a negative effect, while NAA trended to promote rooting of "2nd top node" cuttings. In trials to date water stress seems to lower rooting percentages. Excessive reduction of the leaf left on the cutting appeares to have the same effect $(5,7)$.

Survival after potting of rooted cuttings ranged from 10 to $50 \%$ in spite of the several weaning periods and transplanting methods tried. The reason for this, the most important problem encountered, is not known. This transplanting phase is the highest priority for future work $(9,11)$.

\section{MATERIALS AND METHODS}

For the examination of the influence of some biostimulators of the type IAA and NAA on the rooting percent of the seedlings, on the diameter of the root bale, on the number of roots and on the length of the roots for the species Azaleea indica, an experiment was organized at the University of Oradea, Environmental Faculty, Romania.

The species that were used were chosen taking into account the tendency of the cultivators to spread them more than the others due to their decorative value, to the possibility to multiply by seedlings or by grafting, their resistance to different attacks of diseases and pests: Apollo, Madame John Häerens, Reinold Ambrosius, Memoire August Häerens. 
For the choice of the substances used as stimulators, of the concentrations and the duration of treatment, as starting points were taken the recommendations found in the specialty literature, so that the studied variants were:

$\mathrm{V}_{1}=$ untreated witness;

$\mathrm{V}_{2}=\mathrm{IAA} 500 \mathrm{ppm}$, treatment time one second;

$\mathrm{V}_{3}=\mathrm{IAA} 1000 \mathrm{ppm}$, treatment time one second;

$\mathrm{V}_{4}=\mathrm{IAA} 1500 \mathrm{ppm}$, treatment time one second;

$\mathrm{V}_{5}=\mathrm{NAA} 10 \mathrm{ppm}$, treatment time one second;

$\mathrm{V}_{6}=$ NAA $100 \mathrm{ppm}$, treatment time one second;

$\mathrm{V}_{7}=\mathrm{NAA} 1000 \mathrm{ppm}$, treatment time one second;

$\mathrm{V}_{8}=$ Procaine $0.5 \%$, treatment time one second;

$\mathrm{V}_{9}=$ Procaine $2.5 \%$, treatment time one second;

The solutions IAA, NAA and procaine, have been prepared in the morning of the treatment of the seedlings so that they should not reduce or change their influence. After weighting, they were dissolved one at a time in alcohol of $96^{\circ}$, and the procaine was dissolved directly in water.

The variants were placed straight, with separation strips between them to prevent mutual influence, 50 plants of each species were planted, considering 12 seedlings in a repetition.

The results were statistically processed using the method of the " analyses of variance (ANOVAs)". Two proportion tests were used to determine significant differences in percentage analyses.

\section{RESULTS AND DISCUSSIONS}

The calculations were carried out only for the species azalea Apollo because there are no significant differences among the species. By analysis the data in table 1, we notice that the moment of the appearance of the calus is not the same for all variants, being recorded gaps of 10-13 days. The appearance of the calus was recorded the fastest for variants $\mathrm{V}_{2}$ and $\mathrm{V}_{7}$.

Table 1

The influence of the investigated factors on some phonological determinations for the species azalea Apollo, Oradea2008- 2009

\begin{tabular}{|c|c|c|c|c|c|c|c|}
\hline Var. & $\begin{array}{l}\text { Applied treatement/ } \\
\text { concentration }\end{array}$ & $\begin{array}{c}\text { Date of propa- } \\
\text { gation by } \\
\text { seedlings }\end{array}$ & $\begin{array}{l}\text { Date of the } \\
\text { appearance of } \\
\text { the calus }\end{array}$ & $\begin{array}{l}\text { Date of } \\
\text { the app. } \\
\text { of roots }\end{array}$ & $\begin{array}{l}\text { Date of the } \\
\text { compl. } \\
\text { rooting }\end{array}$ & $\begin{array}{c}\text { Date of } \\
\text { planting in the } \\
\text { flower pot }\end{array}$ & $\begin{array}{l}\text { Days necessary } \\
\text { for rooting }\end{array}$ \\
\hline $\mathrm{V}_{1}$ & Distilled water (Mt) & 21.03 & 23.04 & 01.05 & 17.05 & 20.05 & 67 \\
\hline $\mathrm{V}_{2}$ & IAA $500 \mathrm{ppm}$ & 21.03 & 15.04 & 22.04 . & 30.04 & 20.05 & 40 \\
\hline $\mathrm{V}_{3}$ & IAA 1000 & 21.03 & 20.04 & 28.04 & 06.05 & 20.05 & 46 \\
\hline $\mathrm{V}_{4}$ & IAA 1500 & 21.03 & 20.04 & 28.04 & 07.05 & 20.05 & 47 \\
\hline $\mathrm{V}_{5}$ & NAA 10 & 21.03 & 23.04 & 01.05 & 13.05 & 20.05 & 63 \\
\hline $\mathrm{V}_{6}$ & NAA 100 & 21.03 & 23.04 & 02.05 & 15.05 & 20.05 & 65 \\
\hline $\mathrm{V}_{7}$ & NAA 1000 & 21.03 & 10.04 & 17.05 & 28.04 & 20.05 & 38 \\
\hline $\mathrm{V}_{8}$ & Procaine $0.5 \%$ & 21.03 & 23.04 & 01.05 & 13.05 & 20.05 & 63 \\
\hline $\mathrm{V}_{9}$ & Procaine $2.5 \%$ & 21.03 & 23.04 & 02.05 & 18.05 & 20.05 & 68 \\
\hline
\end{tabular}
significant $=$ over 15.0

The appearance of the first roots was recorded the latest for $V_{2}$, weaker than witness $V_{1}$, and the earliest for $\mathrm{V}_{4}$. The faster appearance of the roots after calusare favours faster complete rooting by reducing the time necessary for rooting. For the variants treated with NAA $1000 \mathrm{ppm}\left(\mathrm{V}_{7}\right)$ and with IAA $1500 \mathrm{ppm}\left(\mathrm{V}_{4}\right)$, the rooting time was shortened a lot.

If the witness $\mathrm{V}_{1}$ needed 67 days, the variants $\mathrm{V}_{2}$ and $\mathrm{V}_{7}$, needed approximately 6 weeks, the rooting time shortening significantly (3 weeks). For these variants we can observe the appearance of the calus, the appearance of the first roots and complete rooting in a reduced number of days.

The species of azalea behave differently at rooting, a situation that is illustrated in practice. The species Madame John Häerens presents the highest percent of rooting of all variants. The use of growth stimulators offers the possibility for these species to multiply constantly through propagation by seedlings, good results being obtained with NAA $1000 \mathrm{ppm}\left(\mathrm{V}_{7}\right)$ with $92 \%$.

The length and diameter of the root bale are indexes that, through the reached value mark the moment of planting in the flower pot of the rooted seedlings. The seedlings can be planted when the diameter of the root bale reaches $1,5-2 \mathrm{~cm}$.

In order of the value of the performed morphological determinations, the best and worst results, according to species, are presented in table 2. The data refer only to the diameter of the root bale, their length being in close and positive correlation with the diameter. 


\begin{tabular}{|c|c|c|}
\hline \multicolumn{3}{|c|}{ lifferent species Oradea 2008-2009 } \\
\hline Species & Good results $(\mathbf{c m})$ & Bad results $(\mathrm{cm})$ \\
\hline August Häerens & $\begin{array}{c}\mathrm{V}_{7}-\mathrm{NAA} 1000 \mathrm{ppm}=2.69 \\
\mathrm{~V}_{2}-\mathrm{IAA} 500 \mathrm{ppm}=2.31\end{array}$ & $\mathrm{~V}_{5}-\mathrm{NAA} 10 \mathrm{ppm}=0.75$ \\
\hline Apollo & $\begin{array}{c}\mathrm{V}_{7}-\mathrm{NAA} 1000 \mathrm{ppm}=2.80 \\
\mathrm{~V}_{2}-\mathrm{IAA} 500 \mathrm{ppm}=2.77\end{array}$ & $\begin{array}{c}\mathrm{V}_{9}-\text { procaine } 2.5 \%=0.78 \\
V_{6}-\text { NAA } 100 \mathrm{ppm}==0.89\end{array}$ \\
\hline Reinhold Ambrosius & $\mathrm{V}_{7}-\mathrm{NAA} 1000 \mathrm{ppm}=1.00$ & $\begin{aligned} \mathrm{V}_{6}-\mathrm{NAA} 100 \mathrm{ppm} & =0.62 \\
\mathrm{~V}_{5}-\mathrm{NAA} 10 \mathrm{ppm} & =0.66\end{aligned}$ \\
\hline $\begin{array}{c}\text { Madame } \\
\text { John Häerens }\end{array}$ & $\mathrm{V}_{4}-\mathrm{IAA} 1500 \mathrm{ppm}=2.14$ & $\begin{array}{l}\mathrm{V}_{8}-\text { procaine } 0.5 \%=0.86 \\
\mathrm{~V}_{5}-\mathrm{NAA} 10 \mathrm{ppm}=0.75\end{array}$ \\
\hline
\end{tabular}

After the statistical calculation performed only on the data referring to the diameter and length of the roots (tables 3 and 4 ), we notive the fact that the rooting stimulators used for azalea have a positive effect both regarding the rooting time and the sizes of the roots, being statistically secured - very significant the variants: IAA $500 \mathrm{ppm}\left(\mathrm{V}_{2}\right)$; IAA $1000 \mathrm{ppm}\left(\mathrm{V}_{3}\right)$, IAA $1500 \mathrm{ppm}\left(\mathrm{V}_{4}\right)$ and NAA $1000 \mathrm{ppm}\left(\mathrm{V}_{7}\right)$.

Also as very significant in the sense of weak rooting were noticed the variants that were treated with: NAA $100 \mathrm{ppm}\left(\mathrm{V}_{6}\right)$ and procaine 2,5\% $\left(\mathrm{V}_{9}\right)$. No significance was recorded for the variants: NAA $10 \mathrm{ppm}\left(\mathrm{V}_{5}\right)$ and procaine $0,5 \%\left(\mathrm{~V}_{8}\right)$.

For the fulfilment of the profitability of the azalea culture the use of stimulants is compulsory.

Table 3

The synthesis of the results regarding the diameter of the roots Oradea 2008-2009

\begin{tabular}{|l|c|c|c|}
\hline \multicolumn{1}{|c|}{ Variant/tratament/conc. (ppm) } & $\begin{array}{c}\text { Average diameter of the } \\
\text { root bale (cm) }\end{array}$ & $\begin{array}{c}\text { \% over the } \\
\text { witness }\end{array}$ & Signification \\
\hline $\mathbf{V}_{\mathbf{1}}$ - Distilled water (Mt) & 1.21 & 100 & - \\
\hline $\mathbf{V}_{\mathbf{2}}$ - IAA 500 & 2.59 & 213 & $\mathrm{xxx}$ \\
\hline $\mathbf{V}_{\mathbf{3}}$ - IAA 1000 & 0.13 & 176 & $\mathrm{xxx}$ \\
\hline $\mathbf{V}_{\mathbf{4}}$ - IAA 1500 & 2.16 & 178 & $\mathrm{xxx}$ \\
\hline $\mathbf{V}_{\mathbf{5}}$ - NAA 10 & 1.01 & 84 & - \\
\hline $\mathbf{V}_{\mathbf{6}}$ - NAA 100 & 0.63 & 52 & 000 \\
\hline $\mathbf{V}_{\mathbf{7}}$ - NAA 1000 & 2.93 & 242 & $\mathrm{xxx}$ \\
\hline $\mathbf{V}_{\mathbf{8}}$ - Procaine 0,5\% & 1.32 & 109 & - \\
\hline $\mathbf{V}_{\mathbf{9}}$ - Procaine 2,5\% & & 49 & 000 \\
\hline DL 5\% & 0.60 & & \\
DL 1\% & 0.28 & & \\
DL 0.1\% & 0.38 & & \\
\hline
\end{tabular}

Note: NS $=$ Non-significant $=$ under $6.0 ; *=$ Significant $=6.0-9.0 ; * *=$ Significantly different $=9.0-15.0 ; * * *=$ very significant $=$ over 15.0

Table 4

The synthesis of the results regarding the length of the roots Oradea 2008-2009

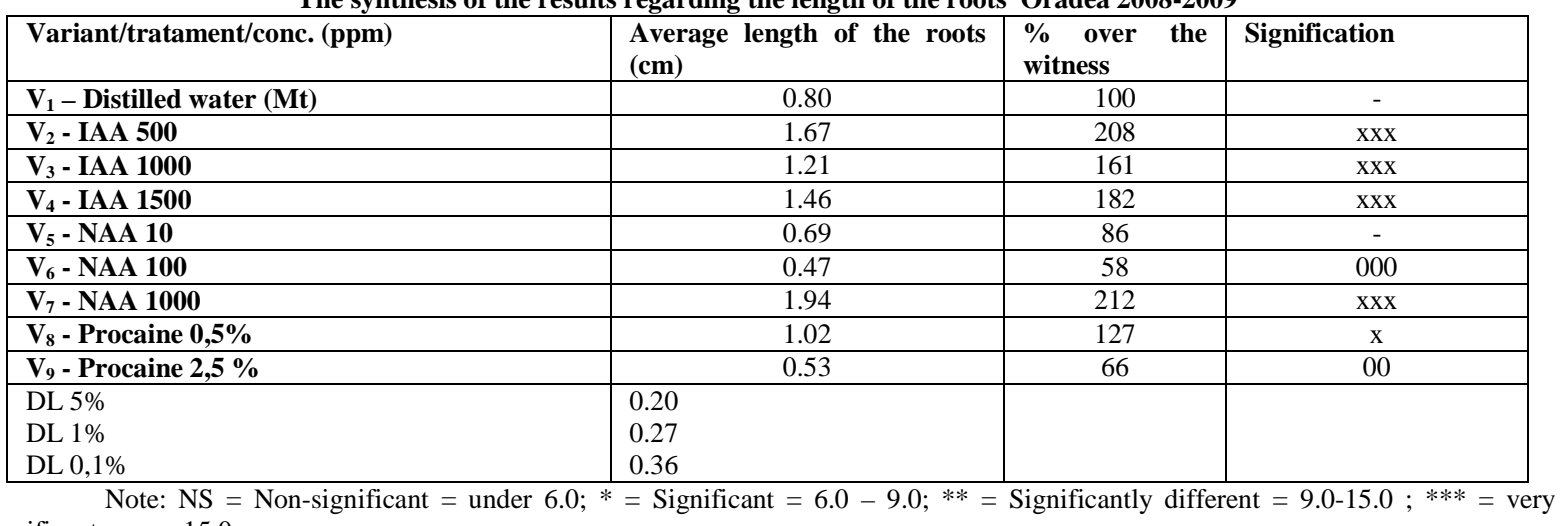
significant $=$ over 15.0

\section{CONCLUSIONS}

- through the use of stimulents, the time necessary for rooting is reduced from 9-11 weeks to 5-6 weeks for azalea seedlings;

- the reduction of the time necessary for rooting removes the exhaustion of the seedlings, determining at the same time a better evolution of the plants in flower pots; 
- for more complete information on the influence of the stimulants on the rooting of azalea plants, we recommend the continuation of the observations on the plants rooted with stimulants also after the planting in the flower pot, following their behaviour and evolution until blooming.

\section{REFERENCES}

1. Bandici Gh. E., -2006. "Fiziologia plantelor"ediția a III-a . EdituraUniversității din Oradea, 374 p.

2. Bandici, Gh.,Vlad, I., - 2000. Efectul unor substanțe bioactive asupra înrădăcinării butaşilor de araucaria. AGRICULTURA, Revistă de ştiință şi practică agricolă, Anul IX, numerele 1-4 (33-36), Cluj-Napoca, pp. 52-55.

3. DeYoe, D. and J. Zaerr. 1976. Indole-3-acetic acid (IAA) in Douglas fir.Plant Physiol. 58:299-303.

4. Gil-Albert, F. and E. Boix . 1978. Effect of treatment with IBA on rooting of ornamental conifers . Acta Hort. No. 79 63-77.

5. Hare, R. 1984. Stimulation of early height growth in longleaf pine with growth regulators. Can. J. For. Res. 14:459-462.

6. Ionică, A., Cachiță-Cosma D.,, Popovici, Gh., Rădulescu, T., 1971, Procaina un medicament care stimulează creşterea şi dezvoltarea plantelor, Farmacia, XIX, 8, pp 501-506.

7. Kramer, P. and T. Kozlowski. 1979. Physiology of woody plants. Academic Press, New York, 811 p.

8. Little, C. and R. Pharis. 1995. Hormonal control of radial and longitudinal growth in the tree stem. In Plant Stems: Physiology and Functional Morphology. Ed. B.L. Gartner. Academic Press, San Diego, pp 281-319.

9. Micu, M., Cachiță-Cosma D., Henegariu O., 1980, Growyh of one zear old Picea abies plants, resulted from seeds treated with procaine peroxide and ultrasounds, Trav. Mus. Hist. Nat. "Grigore Antipa", XIX, pp 21-23.

10. Milică C.I., Sabina Stan, Doina Liana Toma - 1983. "Substanțe bioactive în horticultură". Editura Ceres Bucureşti, $227 \mathrm{p}$.

11. Ross, S., R. Pharis andW. Binder. 1983. Growth regulators and conifers:their physiology and potential uses in forestry. In Plant Growth Regulating Chemicals. Vol. Ed. L. Nickell. CRC Press, Boca Raton, FL, p 35-78.

12. Taiz, L. and E. Zeiger. 2002. Plant physiology. 3rd Ed. Sinauer Associates, MA, p.690 